\title{
THE CONCERN OF THE CHURCH ON THE INCREASE IN VENEREAL DISEASES
}

The Archbishop of York uttered a grave warning as to the growth of venereal disease and made a series of pronouncements on methods of dealing with the problem. In his presidential address to the York Diocesan Conference on July 1st he observed : "There is another matter which ought to cause us grave anxiety. Since the outbreak of war there has been a considerable increase in venereal disease. In syphilis, taking the whole country, there has been an increase of 120 per cent, although I am told on good authority that the proportion of all forms of venereal disease is smaller for this war than it was in the last. The rise in syphilis has been mainly among women, this is additionally serious as they may infect their babies. I need not dwell on the terrible suffering caused by venereal disease, not confined to those who have contracted it by their own act. It is a disease which brings both physical and moral suffering. The problems arising from it concern both Church and State. They must cooperate as far as possible in both prevention and cure.

The Church must help in prevention by giving clear and definite teaching. Increased venereal disease is a symptom of increased moral laxity. Promiscuous intercourse has always been condemned by the Church, not only because of its physical and social dangers, but because it is sin against God. The Christian is bound to make this plain, and all proposed remedies must be judged by this standard. Much more definite and intelligent Christian teaching is required. We must not be satisfied only by asserting authoritatively the Christian standpoint, we must give our reasons for it. At one time the Christian teaching on sex was generally accepted in principle, however widely it might be disregarded in practice. This acceptance can no longer be assumed. There are many who see no harm in promiscuity if the consent of both parties is given. We must be ready therefore to give plainly our reasons for the Christian position.

We must not however rest content with this. There are large numbers who have never come under Christian influence, and there are others too, who, while they recognize the Christian moral standard, have not had the strength to keep it. In war-time especially temptations are very great, large numbers of men and women are far removed from their homes, sometimes doomed to long periods of boredom and sometimes exposed to almost intolerable strain followed by a reaction which for a time weakens the will. One act may condemn a man, his wife and his future children to untold suffering. It is unchristian for us simply to say the man is suffering the due penalty of his sin. Pity should urge us to do all in our power to restore him to health in both body and soul.

\section{Secret Clinics}

There is general agreement on the steps which should be taken in this direction. There are already many clinics open in different parts of the country, but the number is insufficient. Many more are required. And they should be so situated that those who attend them can be certain as far as possible of complete secrecy.

There are some who advocate compulsory notification of the disease. It is indeed illogical that childish complaints have to be notified while this is regarded as unnecessary in the case of this killing disease:- But universal compulsory notification is impossible. It would tend to drive the disease in its early stages underground as the patient would delay consulting the doctor who would have to notify the authorities. And at present there are insufficient doctors in the country to deal with this disease. It may, however, be necessary if it cannot be checked to make it notifiable in certain localities : and I think there is a very strong case for the compulsory notification of babies born with the disease, as a complete cure to save them from lives of suffering is possible by prolonged and early treatment.

\section{Action by Ministry of Health}

There is more difference of opinion as to the steps which should be taken to prevent the spread of the disease. Personally I approve of the action already 
taken by the Ministry of Health. It is reasonable to insist on the compulsory treatment of those who are proved centres of contagion, and it is right that instruction should be given in how to avoid venereal disease, provided such instruction is always accompanied by the statement that there is no safety except in the avoidance of promiscuity. More propaganda is needed to bring home to all both the personal and social dangers incurred by promiscuity, and the vital importance of early treatment if the disease is contracted. Special care should be taken to provide recreation for all isolated camps. Many more women police are required to deal with silly and thoughtless girls who hang about the camps pestering the men and who pay no heed to the remonstrances of voluntary workers.

Our own immediate duty as Church people is to see that our Moral Welfare Work does not lack funds to carry on its essential work; and that individual Christians bear their witness fearlessly and intelligently in upholding the Christian standard. In doing this we must not fall into the error, too often made in the past, of treating sexual wrongdoing as the great sin. Christian morality always regards pride as the sin which above all others separates man from God and his neighbour. If we bear this in mind we shall be the less likely to adopt a superior or rigid attitude to those who have yielded to the sins of flesh. When we condemn the sin, we must not forget to point the way to repentance. And when we exhort men and women to resist this temptation we must not forget to tell them that God is ready to strengthen our weak wills. I have felt it right to speak plainly for we are often accused of refusing to face the hard facts. The younger generation discuss sex problems with great freedom, sometimes with greater freedom than knowledge. We shall never be able to help them if we adopt a cowardly policy of silence. Knowledge of the physical facts of sex is insufficient, what is needed is more intelligent teaching of the Christian view of sex if we are to avoid moral chaos.",

\section{CORRESPONDENCE}

\section{THE NEW JOURNAL}

Sir,-The members of the M.S.S.V.D. and other readers of your Journal will, I am sure, associate themselves with me in congratulating you and your Editorial colleagues on the March number of the British Journal of Venereal Diseases.

Although a war-time production, it appears to me to show several advantages over its former self and especially in the excellent and varied fare which it provides for our consumption. May it grow from strength to strength so that it will become a potent force in the land by stimulating the interest of the medical profession and of the intelligent layman (including women) in the subject of venereal diseases, an interest which has been aroused and which must not again be allowed to slacken.

One hopes too that the Jourkal in its new form may be the means of stimulating research in venereal diseases which has been rather conspicuously absent in this country. In this connection one would like to offer the suggestion that some workable arrangement be made with the United States Public Health Service whereby you, Sir, might be permitted to use in your Journal any of the material contained in its very valuable publication, Venereal Diseases Information.

I should like to endorse everything you say about Col. L. W. Harrison, for without him this Journal could not have achieved its present sturdy condition.

I was interested, Sir, in the very interesting case of gumma of the tongue in a congenital syphilitic recorded by Dr. Morna Rawlins and yourself. These cases are distinctly rare nowadays, and I saw only one such during an experience of over twenty years. What shocks one, however, is your statement that the absolutely typical Hutchinsonian right incisor tooth does not appear to have been recognized as such by officers of the school medical and dental services, and this thirty years after the institution of these services and ninety years after Hutchinson so carefully described them. Obviously our school medical and dental services need some overhauling so that cases of congenital syphilis will not be missed as this one was.- 1 am, etc., 